\title{
Triggering Factors in Patients Diagnosed Urticaria
}

\section{(D) Özge Așkın, (1) Rozerin Neval Altunkalem, (1) Tuğba Kevser Uzunçakmak, (1) Server Serdaroğlu}

Istanbul University-Cerrahpasa, Cerrahpasa Faculty Medicine, Department of Dermatology and Venereology, Istanbul, Turkey

\section{ABSTRACT}

Background: Urticaria is a skin disease that is common in all societies and characterized by itchy and edematous plaques that appear suddenly and disappear spontaneously within the same day. Urticaria that lasts for less than six weeks is called acute, while urticaria that lasts longer and can last for years is chronic. While antihistamines are preferred in the first place in treatment, other treatment options may be considered according to the treatment response. In addition to diagnosis and treatment, it is essential to identify and eliminate triggering factors. Common triggers include physical triggers, foods, medicines, fatigue, stress, infections, smoking, dust, pollen and the premenstrual period.

Materials and Methods: In our study, the files of 145 patients who applied to the dermatology outpatient clinic between 1 January 2019 and 1 September 2020 were retrospectively scanned.

Results: Ninety-one (62.7\%) of the patients were female, 54 (37.2\%) were male. Average age was 38.9. While triggering factors are seen in 62 (42.7\%) of the patients; dermographism was seen in 37 (25.5\%) of the patients. Trigger factors were common in women and between the ages of 20 and 40 . Physical triggers were the most common triggers, followed by foods and drugs.

Conclusion: Urticaria is a dermatological emergency affecting the patient's quality of life. Therefore, success in treatment is very important. Finding and removing triggering factors besides pharmacological treatment will significantly improve the patient's quality of life.

Keywords: Urticaria, Triggering factors, Physical triggers

\section{Introduction}

Urticaria is a skin disease that is common in all societies and characterized by itchy and edematous plaques that appear suddenly and disappear spontaneously within 24 hours. It occurs for different reasons and different mechanisms and is classified in a heterogeneous way [1].

Apart from the acute forms of the disease that last less than about six weeks, there are chronic forms that last for years, their types with angioedema, and less frequent inducible or syndromic forms. Approximately half of the cases are accompanied by angioedema [2].
Urticaria significantly adversely affects the quality of life of patients, especially in its chronic forms, and can lead to socio-economic problems. Therefore, diagnosis and treatment selection is very important [3].

The choice of treatment is usually tailored to the duration, frequency and response of the attack and is individualized for each patient. In the treatment, second-generation $\mathrm{H} 1$ antihistamines, but also H2 antihistamines, hydroxyzine, doxepin, oral glucocorticoids, omalizumab/anti-immunoglobulin (Ig) E therapy, phototherapy, physical desensitization, immunomodulatory agents are used $[4,5]$. 
In addition to pharmacological treatment, it is also important to find and avoid triggering factors. Common triggers include physical triggers (dermographism, cold urticaria, pressure urticaria, solar urticaria, heat urticaria, vibration angioedema, cholinergic urticaria, contact urticaria, aquagenic urticaria), foods (eggs, milk, soy, peanuts in children; fish, shellfish, seafood, nuts in adults), medicines [aspirin and other non-steroidal anti-inflammatory drugs (NSAIDS), angiotensin converting enzyme (ACE) inhibitors, codeine, penicillin], fatigue, stress, infections, smoking, dust, pollen and the premenstrual period $[6,7,8]$.

In this study, it was aimed to determine the triggering factors in our patients with urticaria.

\section{Materials and Methods}

One hundred forty-five patients who applied and treated in the Dermatology Department of Istanbul University-Cerrahpasa, Cerrahpasa Faculty of Medicine between 2019-2020 were included in the study. All the patients diagnosed with urticaria the files were examined and their age, gender, and predisposing factors were analyzed retrospectively.

\section{Statistical Analysis}

Statistical analyzes were performed using Statistical Package for the Social Sciences version 21 software. The compliance of the variables to normal distribution was examined by visual (histogram and probability graphs) and analytical methods (Kolmogorov-Smirnov/ Shapiro-Wilk tests). Descriptive analyzes were given using mean and standard deviation for normally distributed variables, median and interquartile range for non-normally distributed variables, and frequency tables for categorical variables.

\section{Results}

Ninety-one (62.7\%) of the patients were female, 54 (37.2\%) were male. Average age was 38.9. While triggering factors are seen in 62 $(42.7 \%)$ of the patients; dermographism was seen in 37 (25.5\%) of the patients. Trigger factors were common in women and between the ages of 20 and 40 . Physical triggers were the most common triggers, followed by foods and drugs (Table 1).

Aquagenic urticaria was the most common physical trigger. Fish and nuts were the most common causes of food-related urticaria. NSAID were held responsible for drug-related urticaria to a large extent. The least common trigger factor was the premenstrual period (Table 2).

\section{Discussion}

There are many factors that are held responsible in the etiology of urticaria. Some of these are the primary causes, while others are the factors that trigger the lesions and cause exacerbation. While these triggering factors are seen in $10-20 \%$ of patients in many studies, etiology cannot be found in $50 \%$ of the patients $[9,10,11]$.
In a study in which triggering factors were investigated only in pediatric population, this rate was found to be $21-55 \%$. In another study, while $75.9 \%$ of the patients described the triggering factor, only $36.3 \%$ of the tests performed rash after the triggers $[12,13]$.

In our study, triggering factors were seen at a rate of $42.7 \%$.

As in other studies, association with triggering factors was more common in female and young adult patients in our study $[14,15]$.

The most common triggering factor was physical triggers in many studies in the literature, as in our study. It was followed by foods and drugs $[14,15,16]$.

Studies show that foods are responsible for $5.3 \%$ of acute urticaria cases. IgE mediated food allergy is rarely observed in urticaria. In IgE-mediated urticaria, if the responsible food is eliminated from the diet, the lesions disappear within 24-48 hours. The most common foods that caused urticaria were eggs and milk in children, while fish and shellfish in adults. There was no pediatric age group in our study. In adults, fish were often found to be the trigger factor, in accordance with the literature $[17,18]$.

In some of the studies, antibiotics are the most frequently held responsible group for drug-induced urticaria, while in others NSAIDs. Urticaria is estimated to occur in $0.1 \%$ to $0.3 \%$ of the patients who use NSAIDs. NSAID and aspirin use is not recommended, especially in chronic urticaria cases. In our study, it was observed that NSAIDs triggered more urticaria attacks compared to other drugs [19,20]. ACE inhibitors can cause angioedema. Therefore, it is not appropriate to use ACE inhibitors in urticaria cases accompanied by angioedema [21]. In our study, there was no patient group in whom urticaria or angioedema was observed with ACE inhibitors.

In cases of physical and emotional fatigue and stress, both lesions and pruritus may increase, the patient is recommended to stay away from stressful environments that they are aware of and can avoid. Some patients may benefit from psychological support [22].

\section{Table 1. Trigger factors}

\begin{tabular}{|l|l|}
\hline Trigger factors & Number of cases (\%) \\
\hline Physical triggers & $34(23.4)$ \\
\hline Foods & $14(9.6)$ \\
\hline Drugs & $11(7.5)$ \\
\hline Premenstrual period & $3(2)$ \\
\hline
\end{tabular}

\section{Table 2. Physical triggers}

\begin{tabular}{|l|l|}
\hline Physical triggers & Number of cases (\%) \\
\hline Aquagenic urticaria & $11(7.5)$ \\
\hline $\begin{array}{l}\text { Cholinergic urticaria (physical exercise, stress, } \\
\text { hot shower) }\end{array}$ & $7(4.8)$ \\
\hline Pressure urticaria & $5(3.4)$ \\
\hline Cold urticaria & $4(2.7)$ \\
\hline Solar urticaria & $4(2.7)$ \\
\hline Heat urticaria & $2(1.3)$ \\
\hline Contact urticaria & $1(0.6)$ \\
\hline
\end{tabular}


More rarely reported triggers/aggravates are cigarette smoke, house dust mites, pollen, mold and spores, and there are cases with premenstrual exacerbation [23]. The patient should be informed about all these potential exacerbations.

\section{Study Limitation}

The limitation of the study was the inability to test patients for physical triggers.

\section{Conclusion}

According to the results of this study, the most common triggers of urticaria are physical triggers, foods and drugs. In addition to pharmacological treatment, avoiding these triggers will significantly increase the quality of life of patients.

\section{Ethics}

Ethics Committee Approval: The study were approved by the Istanbul University Cerrahpasa-Cerrahpasa Faculty Medicine Local Ethics Committee (approval number: 83045809-604.01.02-103775, date: June 2, 2021).

Informed Consent: Retrospective study.

Peer-review: Internally peer-reviewed.

\section{Authorship Contributions}

Surgical and Medical Practices: S.S., Concept: S.S., Ö.A., Design: Ö.A., R.N.A., Data Collection or Processing: Ö.A., R.N.A., Analysis or Interpretation: Ö.A., T.K.U., Literature Search: Ö.A., R.N.A., Writing: Ö.A., R.N.A.

Conflict of Interest: No conflict of interest was declared by the authors.

Financial Disclosure: The authors declared that this study received no financial support.

\section{References}

1. Zuberbier T, Aberer W, Asero R, Bindslev-Jensen C, Brzoza Z, Canonica GW, Church MK, Ensina LF, Giménez-Arnau A, Godse K, Gonçalo M, Grattan C, Hebert J, Hide M, Kaplan A, Kapp A, Abdul Latiff AH, Mathelier-Fusade P, Metz M, Saini SS, Sánchez-Borges M, Schmid-Grendelmeier P, Simons FE, Staubach P, Sussman G, Toubi E, Vena GA, Wedi B, Zhu XJ, Nast A, Maurer M; Dermatology Section of the European Academy of Allergy and Clinical Immunology; Golbal Allergy and Asthma European Network; European Dermatology Forum; World Allergy Organization. Methods report on the development of the 2013 revision and update of the EAACI/GA2 LEN/EDF/WAO guideline for the definition, classification, diagnosis, and management of urticaria. Allergy 2014;69:1-29.

2. Yuan Y, Xiao Y, Chen X, Li J, Shen M. A Systematic Review and Meta-Analysis of Health Utility Estimates in Chronic Spontaneous Urticaria. Front Med (Lausanne) 2020;7:543290.

3. Weldon DR. Quality of life in patients with urticaria. Allergy Asthma Proc 2006;27:96-99.

4. Pozderac I, Lugović-Mihić L, Artuković M, Stipić-Marković A, Kuna M, Ferček I. Chronic inducible urticaria: classification and prominent features of physical and non-physical types. Acta Dermatovenerol Alp Pannonica Adriat 2020;29:141-148.
5. Maurer M, Metz M, Brehler R, Hillen U, Jakob T, Mahler V, Pföhler C, Staubach P, Treudler R, Wedi B, Magerl M. Omalizumab treatment in patients with chronic inducible urticaria: A systematic review of published evidence. J Allergy Clin Immunol 2018;141:638-649.

6. Maurer M, Fluhr JW, Khan DA. How to Approach Chronic Inducible Urticaria. J Allergy Clin Immunol Pract 2018;6:1119-1130.

7. Abajian M, Schoepke N, Altrichter S, Zuberbier T, Maurer M. Physical urticarias and cholinergic urticaria. Immunol Allergy Clin North Am 2014;34:73-88.

8. Maurer M, Ortonne JP, Zuberbier T. Chronic urticaria: a patient survey on quality-of-life, treatment usage and doctor-patient relation. Allergy 2009;64:581-588.

9. Folci M, Ramponi G, Brunetta E. A Comprehensive Approach to Urticaria: From Clinical Presentation to Modern Biological Treatments Through Pathogenesis. Adv Exp Med Biol 2021 Jan 1.

10. Weller K, Giménez-Arnau A, Grattan C, Asero R, Mathelier-Fusade P, Bizjak M, Hanna M, Maurer M; CURE Investigators. The Chronic Urticaria Registry: rationale, methods and initial implementation. J Eur Acad Dermatol Venereol 2020 Sep 18.

11. Curto-Barredo L, Pujol RM, Roura-Vives G, Gimenez-Arnau AM. Chronic urticaria phenotypes: clinical differences regarding triggers, activity, prognosis and therapeutic response. Eur J Dermatol 2019;29:627-635.

12. Caffarelli C, Duse M, Martelli A, Calvani M, Cardinale F, Chiappini E, Marseglia GL, Miraglia Del Giudice M, Tosca MA, Castagnoli R, Brambilla I, Santoro A, Procaccianti M, Giannetti A, Ricci G, Minasi D. Urticaria in childhood. Acta Biomed 2020;91:2020013.

13. Ataseven A, Durmaz K, Ozer I, Dursun R. Gallstones at chronic spontaneous urticaria patients: A retrospective clinical study. Dermatol Ther 2020;33:13212.

14. Hon KL, Leung AKC, Ng WGG, Loo SK. Chronic Urticaria: An Overview of Treatment and Recent Patents. Recent Pat Inflamm Allergy Drug Discov 2019;13:27-37.

15. Schaefer P. Acute and Chronic Urticaria: Evaluation and Treatment. Am Fam Physician 2017;95:717-724.

16. Sánchez J, Amaya E, Acevedo A, Celis A, Caraballo D, Cardona R. Prevalence of Inducible Urticaria in Patients with Chronic Spontaneous Urticaria: Associated Risk Factors. J Allergy Clin Immunol Pract 2017;5:464-470.

17. Skrie VC, Orellana JC. Reacción adversa por aditivos alimentarios en un paciente pediátrico [Adverse reaction to food additives in a pediatric patient]. Rev Alerg Mex 2018;65:187-191.

18. Jaros J, Shi VY, Katta R. Diet and Chronic Urticaria: Dietary Modification as a Treatment Strategy. Dermatol Pract Concept 2019;10:2020004.

19. Rauscher C, Petrov AA, Fajt ML. Factors Associated with Self-Reported Drug Allergies in a Large Chronic Spontaneous Urticaria Cohort. Curr Drug Saf 2020 Oct 2.

20. Kowalski ML, Woessner K, Sanak M. Approaches to the diagnosis and management of patients with a history of nonsteroidal anti-inflammatory drugrelated urticaria and angioedema. J Allergy Clin Immunol 2015;136:245-251.

21. Rasmussen ER, Mey K, Bygum A. Angiotensin-converting enzyme inhibitorinduced angioedema--a dangerous new epidemic. Acta Derm Venereol 2014:94:260-264.

22. Varghese R, Rajappa M, Chandrashekar L, Kattimani S, Archana M, Munisamy M, Revathy G, Thappa DM. Association among stress, hypocortisolism, systemic inflammation, and disease severity in chronic urticaria. Ann Allergy Asthma Immunol 2016;116:344-348.

23. Chow SK. Management of chronic urticaria in Asia: 2010 AADV consensus guidelines. Asia Pac Allergy 2012;2:149-160. 